\title{
Boron Transport and Soluble Carbohydrate Concentrations in Olive
}

\author{
Slavko Perica, Nacer Bellaloui, Carl Greve, Hening Hu, and Patrick H. Brown ${ }^{1}$ \\ Department of Pomology, University of California, Davis, CA 95616
}

\begin{abstract}
ADDitional INDEX wORDS. sugar, sugar alcohol, translocation, isotope, Olea europaea
Abstract. Boron (B) remobilization, mannitol and glucose concentrations, and the effect of B application on changes in soluble carbohydrates were investigated in various organs of bearing 'Manzanillo' olive trees (Olea europaea $\mathrm{L}$. 'Manzanillo'). Following foliar ${ }^{10} \mathrm{~B}$ application to leaves of various ages, there was significant ${ }^{10} \mathrm{~B}$ export out of the treated leaves, and significant ${ }^{10} \mathrm{~B}$ enrichment in nontreated adjacent organs, including inflorescences and fruit. Results demonstrated that $B$ can be remobilized from leaves of various ages, and that foliar-applied B is phloem mobile in olive. Soluble carbohydrate analysis determined that mannitol and glucose are the predominant sugars in all organs analyzed and that the mannitol concentration in the leaves is adequate to account for all $B$ transport. This is consistent with observations in other species, where the presence of mannitol is known to facilitate phloem $B$ transport through formation of a mannitol-B complex. Previous reports have indicated that B application can alter carbohydrate metabolism. In the present study, foliar B application significantly suppressed glucose concentration in the leaf petioles of all ages and increased mannitol in petioles of the current-year-developed leaves.
\end{abstract}

Relative phloem mobility of B in a particular species influences that species responsiveness to foliar B fertilization and sensitivity to fluctuations in ambient soil B concentration (Brown and Shelp, 1997). Knowledge of phloem B mobility at various stages of plant growth is therefore important for efficient management of B nutrition in horticultural species.

Indirect evidence of phloem B remobilization from olive (Olea europaea) leaves during flowering has been reported by Delgado et al. (1994), but B remobilization has not been determined during other stages of olive fruit development. Phloem mobility of $\mathrm{B}$ would be expected given the abundance of mannitol in olive leaves (Drossopoulos and Niavis, 1988; Flora and Madore, 1993; Tattini et al., 1996) and olive fruit (Garcia et al., 1995), and the demonstrated phloem mobility of the B-mannitol complex in other species (Hu et al., 1997). The concentration of mannitol in olive leaves and bark, however, varies with stage of development and time of year (Drossopoulos and Niavis, 1988). Thus, it is unknown if leaves of different ages vary in terms of B mobility and if the mobility of B correlates closely with the mannitol production capacity. Therefore, this study was conducted to determine phloem B mobility during different stages of fruit and leaf development in olive and to determine if leaves of different ages have a different capacity for mannitol production that varies with B remobilization.

\section{Materials and Methods}

Field experiments were carried out in 1999 using bearing 35year-old 'Manzanillo' olive trees growing in an experimental orchard at the University of California, Davis. Each of the three experiments described was performed on trees selected from within a large uniform planting. In all experiments where isotopically enriched ${ }^{10} \mathrm{~B}$ was used, the procedures were as follows: foliar isotopically enriched ${ }^{10} \mathrm{~B}$ was applied to leaves at three

Received for publication 3 July 2000. Accepted for publication 20 Jan. 2001. This work was supported by U.S. Department of Agriculture Grant, CSRS 9801010. The senior author acknowledges financial support from the Fulbright Program. The cost of publishing this paper was defrayed in part by the payment of page charges. Under postal regulations, this paper therefore must be hereby marked advertisement solely to indicate this fact.

${ }^{1}$ Corresponding author; e-mail phbrown@ucdavis.edu. stages: during rapid inflorescence expansion (21 Apr.), 2 weeks before full bloom (6 May), and during rapid fruit growth (4 Aug.). Where B was used, it was applied to all leaves on each selected shoot/branch (described below). The distal 75\% length of each leaf blade was immersed for $5 \mathrm{~s}$ in a $100 \mathrm{~mm}$ B solution supplied as ${ }^{10} \mathrm{~B}$-enriched boric acid $\left(99.43 \%{ }^{10} \mathrm{~B}: 0.57 \%{ }^{11} \mathrm{~B}\right.$, Eagle Picher, Inc., Quapaw, Okla.). This approach was required to avoid contamination of the petiole with isotopically enriched $\mathrm{B}$. The $\mathrm{B}$ solution contained $0.05 \%$ (v/v) L-77 (Loveland Industries Inc., Greeley, Colo.) as a surfactant and was adjusted to $\mathrm{pH} 5.5$ with 0.1 $\mathrm{mol} \cdot \mathrm{L}^{-1}$ of $\mathrm{NaOH}$. Care was taken not to contaminate nontreated plant parts, which included petioles, inflorescences, peduncles, and fruits, and which, along with treated leaves, were sampled for $\mathrm{B}$ analysis at 1,5 , and $15 \mathrm{~d}$ after the treatments were applied.

BORON TRANSLOCATION FROM 1-YEAR-OLD LEAVES (EXPT. 1). TO study ${ }^{10} \mathrm{~B}$ disappearance from 1-year-old leaves (defined as mature fully developed leaves formed during the previous growing season, and subtending an inflorescence in their axes), 12 branches on each of five replicate trees were selected. Boron was applied to the leaves of six branches of each tree on 21 Apr., and the other six branches were used as controls. Each of the six branches was randomly assigned a number. For the first sampling, leaves were collected in such a way that for branches 1 and 4 , leaf node positions 1 and 4 (counting from the basal) were sampled; for branch 2 and 5, leaf node positions 2 and 5 were sampled; for branch 3 and 6 , leaf node positions 3 and 6 were sampled. For the second and third sampling, the leaf node position was varied accordingly to avoid systematic sampling error. Each sampling date replicate consisted of 24 leaves with four leaves from each branch.

LABELED B ACCUMULATION IN INFLORESCENCE (EXPT. 2). To study ${ }^{10} \mathrm{~B}$ accumulation in inflorescences, the same $\mathrm{B}$ application procedures as described above for the 1-year-old leaves were made on 6 May to leaves of five additional replicate trees. Also, the same sampling procedure as in Expt. 1 was used, but here inflorescences were sampled instead of leaves. Each sampling date replicate consisted of 24 inflorescences, four from each branch.

MANNITOL PRODUCTION AND B EXPORT (EXPT. 3). To study the relationship between mannitol production and ${ }^{10} \mathrm{~B}$ export, an additional 25 bearing trees were chosen, and twelve 2 -year-old branches per tree were tagged. Selection of branches was made such that each branch carried 2-year-old leaves, 1-year-old leaves, and 
fully developed and developing leaves of the current year (the later were defined as leaves at the shoot tip that were less than half the length of fully expanded leaves). Over the experimental period average dry weight (DW) of these leaves increased $<5 \%$. This increase was not statistically significant. The branches averaged 50 $\mathrm{cm}$ long with little lateral branching. In order to obtain uniformity, some fruit and leaves on each selected branch were removed before B application so that eight fruit and six leaves of each of the four leaf types remained on a branch. On 4 Aug., six leaves on one half (six) of the selected branches per tree (all leaf ages) were labeled with ${ }^{10} \mathrm{~B}$ enriched boric acid, while the other half served as controls.

Each sample was collected from six branches per tree with two leaves from each age category (for leaf position see Expt. 1) at 1, 5, and $15 \mathrm{~d}$ after ${ }^{10} \mathrm{~B}$ application. Samples collected from five individual trees were then pooled to provide five replicates with 60 leaves per replicate for analysis. The samples were separated immediately into petioles, leaf blades, peduncles, and fruit, then were placed in an ice chest. These samples were quickly transferred to the laboratory where each sample was subdivided. One subsample was used for B analysis and the other was quickly frozen and kept at $-80{ }^{\circ} \mathrm{C}$ for soluble carbohydrate analyses. Shoot tips were sampled only on the first and fifteenth day after application.

BORON ANALYSIS. All tissues were washed for $1 \mathrm{~min}$ in deionized water, dried at $70{ }^{\circ} \mathrm{C}$ for $72 \mathrm{~h}$, ground to pass a $30-$ mesh $(0.85-\mathrm{mm})$ screen, and ashed at $500{ }^{\circ} \mathrm{C}$ for $4 \mathrm{~h}$. After ashing, samples were dissolved in $10 \mathrm{~mL}$ of $1 \mathrm{~mol} \cdot \mathrm{L}^{-1} \mathrm{HNO}_{3}$ and heated to $90^{\circ} \mathrm{C}$ for 25 min. Boron concentration in the samples was determined by inductively coupled plasma-mass spectrometry (SCIEX ELAN 500 ICP-MS, Perkin Elmer, Norwalk, Conn.) as described previously (Brown and $\mathrm{Hu}, 1994$ ).

Soluble CARBOHYDRATE ANALYSIS. Leaf samples collected $24 \mathrm{~h}$ after initiation of Expt. 3 above, were used to determine soluble carbohydrate. One gram or the total available sample of preweighed frozen tissue was homogenized in a Polytron (Biospec Products, Inc., Dremel, WI) in $10 \mathrm{~mL}$ deionized cold water. The extract was then quickly heated in a boiling water bath for $10 \mathrm{~min}$ to denature the enzymes. After centrifugation at $1000 g_{n}$ for $10 \mathrm{~min}$ the supernatant was collected and lyophilized. The lyophilized material was used for soluble carbohydrate analysis according to Greve and Labavitch

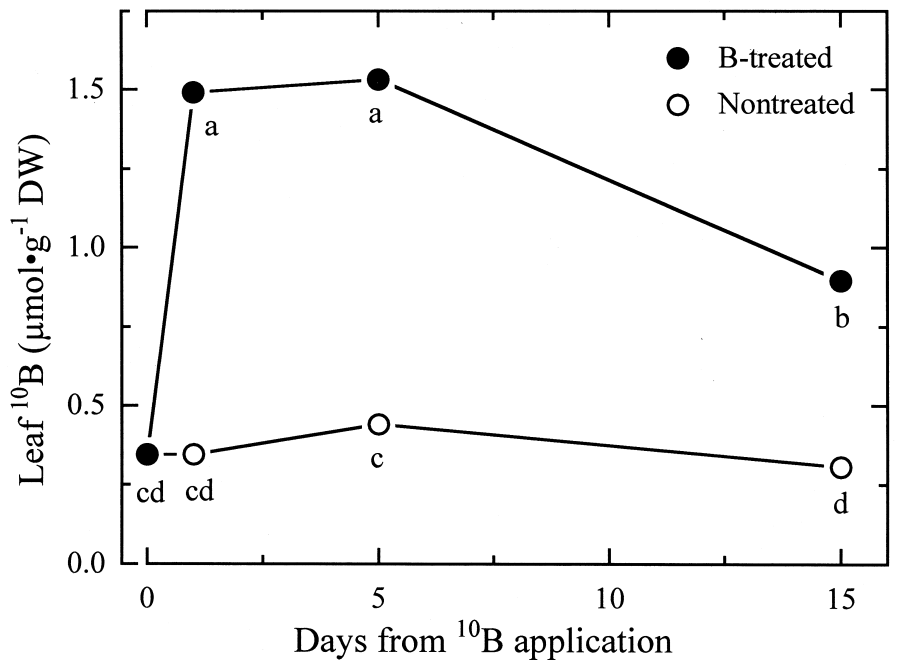

Fig. 1. Changes in leaf ${ }^{10} \mathrm{~B}$ concentration after foliar application of $100 \mathrm{~mm}{ }^{10} \mathrm{~B}$ enriched boric acid to mature 1-year-old leaves on 21 Apr. Boron concentration on day 0 preceded foliar application. Data points with different letters differ at $P<0.05$ by Fisher's protected LSD. Mean separation $(\mathrm{n}=5)$ is within B treatments and across dates.
(1991) with slight modification. An internal standard of $50 \mu \mathrm{g}$ of xylose was added to each sample. Four hundred microliters of acetic anhydride and $60 \mu \mathrm{L}$ of 1-methyl imidazol was added to acetylate the sugars. After $10 \mathrm{~min}, 2 \mathrm{~mL}$ of deionized water was added to stop the reaction. The acetylated sugars were partitioned in $2 \mathrm{~mL}$ dichloromethane and dried. Acetylated samples were then dissolved in $200 \mu \mathrm{L}$ of acetone and analyzed using a Perkin Elmer 8320 gas chromatograph (GC) with a flame ionization detector (Perkin Elmer, Norwalk, Conn.). Additional confirmation of the compounds was carried out using a GC (model 5890; Hewlett-Packard, Palo Alto, Calif.) fitted with mass-selective detector (model 5970; Hewlett-Packard), operated as described earlier(Greve andLabavich, 1991).

EXPERIMENTAL DESIGN AND DATA ANALYSIS. For all experiments, randomized complete block designs were used. All statistical analysis was performed using the SuperAnova statistical analysis program (Abacus Concepts, Berkeley, Calif.).

\section{Results}

During the experimental periods no significant change in leaf DW was observed, though there was a small but nonsignificant increase in DW of developing leaves (5\%). Results are therefore presented on a concentration basis to allow comparisons of $\mathrm{B}$ concentration between tissues and leaf ages. In the absence of significant changes in leaf dry matter, reductions or increases in concentration of applied label accurately reflect export or import of $\mathrm{B}$, from or into, that tissue. Appearance of excess ${ }^{10} \mathrm{~B}$ in nontreated organs represents unequivocal proof of B mobilization out of treated leaves.

BORON TRANSLOCATION FROM 1-YEAR-OLD LEAVES (EXPT. 1). One day after application of ${ }^{10} \mathrm{~B}$ to olive leaves, a greater than 4-fold increase in ${ }^{10} \mathrm{~B}$ concentration was observed in treated compared with nontreated leaves (Fig. 1). This high concentration of ${ }^{10} \mathrm{~B}$ remained essentially unchanged for the first $5 \mathrm{~d}$ after application. After $15 \mathrm{~d}$, ${ }^{10} \mathrm{~B}$ concentration in the treated leaves had decreased by $40 \%$. There was no significant change in ${ }^{10} \mathrm{~B}$ concentration in the control leaves during this time. The significant decrease of ${ }^{10} \mathrm{~B}$ in the treated leaves but not in the control leaves, indicates that foliar applied ${ }^{10} \mathrm{~B}$ had been translocated out of the leaf during this time period. This time frame, $\approx 1$ month before full bloom, corresponded to the time of rapid inflorescence development.

LABELED B ACCUMULATION IN INFLORESCENCE (EXPT. 2). Translocation of foliar applied ${ }^{10} \mathrm{~B}$ out of the treated leaves was confirmed by isotopic enrichment of nontreated, adjacent inflorescences (Fig. 2). A significant (39\%) enrichment of ${ }^{10} \mathrm{~B}$ in the inflorescences at day 15 was observed. This suggests that a portion of ${ }^{10} \mathrm{~B}$ content in the inflorescence was derived from a single foliar application of ${ }^{10} \mathrm{~B}$ to the adjacent leaves. The presence or absence of inflorescences, however, did not significantly alter the disappearance of ${ }^{10} \mathrm{~B}$ from labeled leaves (data not presented).

UPTAKE AND EXPORT OF FOLIAR APPLIED B (EXPT. 3). Following ${ }^{10} \mathrm{~B}$ application in the summer (4 Aug.), tissue ${ }^{10} \mathrm{~B}$ increased in all treated leaves (Fig. 3). The greatest increase in ${ }^{10} \mathrm{~B} 1 \mathrm{~d}$ after labeling was obtained in the 2-year-old leaves (5.6-fold increase), followed by 1 year-old (3.9-fold increase), and developed (3.4 fold increase) or developing leaves (3.4-fold increase). There was a trend for ${ }^{10} \mathrm{~B}$ concentration in all tissues to decrease with time, but the rate of ${ }^{10} \mathrm{~B}$ disappearance differed among leaves of different ages. Thus, at day fifteen, 2-year-old and 1-year-old leaves had exported a significant fraction $(43 \%$, and $35 \%)$ of the ${ }^{10} \mathrm{~B}$ present $1 \mathrm{~d}$ after application. A 


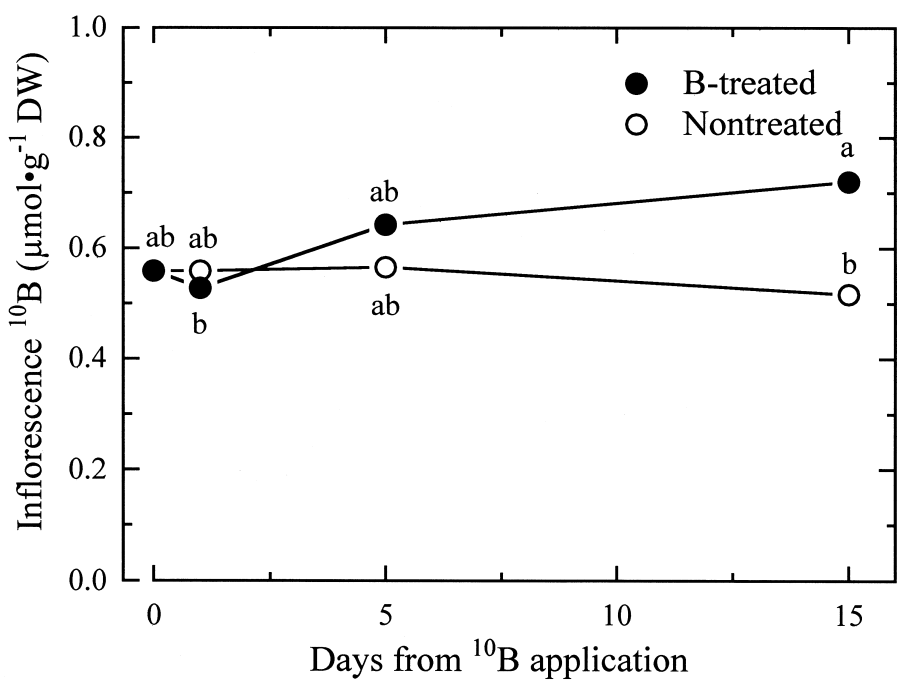

Fig. 2. Changes in inflorescence ${ }^{10} \mathrm{~B}$ concentration after $100 \mathrm{~mm}{ }^{10} \mathrm{~B}$-enriched boric acid foliar application on 6 May to adjacent mature leaves. Boron concentration on day 0 preceded foliar application. Data points with different letters differ at $P<0.05$ by Fisher's protected LSD. Mean separation $(\mathrm{n}=5)$ is across $\mathrm{B}$ treatments and across dates.

small but nonsignificant decrease in ${ }^{10} \mathrm{~B}$ was also observed in current year leaves.

In the nontreated leaves there was a clear and significant increase in leaf tissue B concentration from the oldest to youngest leaves, i.e., 2-year-old leaves had the lowest, while the current-year-developing leaves had highest ${ }^{10} \mathrm{~B}$ concentration (Fig. 3). This decline in tissue $\mathrm{B}$ concentration from young to old leaves is characteristic of a species with phloem B mobility (Brown et al., 1999b).

As verification of ${ }^{10} \mathrm{~B}$ movement out of the labeled leaves, a significant ${ }^{10} \mathrm{~B}$ enrichment was detected in petioles of all age groups (Fig. 4). At day 1 , all petioles in ${ }^{10} \mathrm{~B}$-treated leaves showed significantly higher ${ }^{10} \mathrm{~B}$ concentration than that of the controls with the exception of the petioles in developed leaves. At day 5, petioles of ${ }^{10} \mathrm{~B}$ treated leaves also showed significantly higher ${ }^{10} \mathrm{~B}$ concentration than that of the controls in all age groups except the petioles of 2-year-old leaves. Although the disappearance of ${ }^{10} \mathrm{~B}$ from current-year-developed and developing leaves was not statistically significant(Fig. 3), there was significant enrichment of ${ }^{10} \mathrm{~B}$ in the petioles. This significant enrichment of ${ }^{10} \mathrm{~B}$ in petioles but not the blades of developing and current year leaves, is likely a consequence of the smaller tissue DW of petioles with respect to leaves. Changes in ${ }^{10} \mathrm{~B}$ content of the petiole as ${ }^{10} \mathrm{~B}$ is exported from the leaf blade, will result in a proportionally greater shift in B concentration in petioles than was observed in the leaf blade. These results indicate that olive leaves of all ages have the ability to take up and to retranslocate foliar applied B though the extent of retranslocation is greatest in mature leaves.

Translocation of summer-applied foliar ${ }^{10} \mathrm{~B}$ from treated leaves was further confirmed with the isotopic enrichment of nontreated adjacent fruit (Fig. 5), peduncles and terminal shoot tips (data not presented). As was observed for the inflorescence, a significant enrichment of fruit was recorded at day 15 , which showed a $61 \%$ higher ${ }^{10} \mathrm{~B}$ concentration in the treated compared to nontreated controls (Fig. 5). Again, this clearly indicates that a significant contribution to the fruit ${ }^{10} \mathrm{~B}$ concentration was made from a single foliar ${ }^{10} \mathrm{~B}$ application to adjacent leaves. ${ }^{10}$ Boron concentration in the peduncles was also significantly increased by foliar ${ }^{10} \mathrm{~B}$ labeling (results not presented). At day 15, peduncles from adjacent leaves receiving foliar ${ }^{10} \mathrm{~B}$ had a $47 \%$ higher ${ }^{10} \mathrm{~B}$ concentration than those of controls. Similarly a $41 \%$ increase in ${ }^{10} \mathrm{~B}$ concentration was observed in the growing shoot tips on branches in which proximally matured leaves had received foliar ${ }^{10} \mathrm{~B}$ compared with the control (results not presented).

Changes in mannitol and glucose concentrations (eXPT. 3). Water-soluble sugar analyses were carried out on leaf and petiole samples taken 1d (5 Aug.) after B application. Mannitol and glucose were the predominant sugars in the samples. The concentration of mannitol in the leaves averaged $25 \mu \mathrm{mol} \cdot \mathrm{g}^{-1}$ fresh weight (FW), and was similar in leaves of all ages and B treatment (data not presented).

In contrast to the leaf blade, the concentration of mannitol in the leaf petioles differed significantly depending on leaf age (Fig. 6 ). Among the petioles of mature developed leaves, the highest concentration was found in the oldest petioles, followed by 1year-old and current-year-developed leaves. Within the B treatment developing leaves had significantly higher mannitol concentration than that of older leaves. Boron application signifi-

Fig. 3. Changes in leaf ${ }^{10} \mathrm{~B}$ concentration after $100 \mathrm{~mm}{ }^{10} \mathrm{~B}$-enriched boric acid foliar application on 4 Aug.; (A) 2-year-old leaves, (B) 1-year-old leaves, (C) current year developed leaves, and (D) developing leaves. Boron concentration on day 0 preceded foliar application. Data points with different letters differ at $P<0.05$ by Fisher's protected LSD. Mean separation $(\mathrm{n}=5)$ is within $\mathrm{B}$ treatments and across dates.

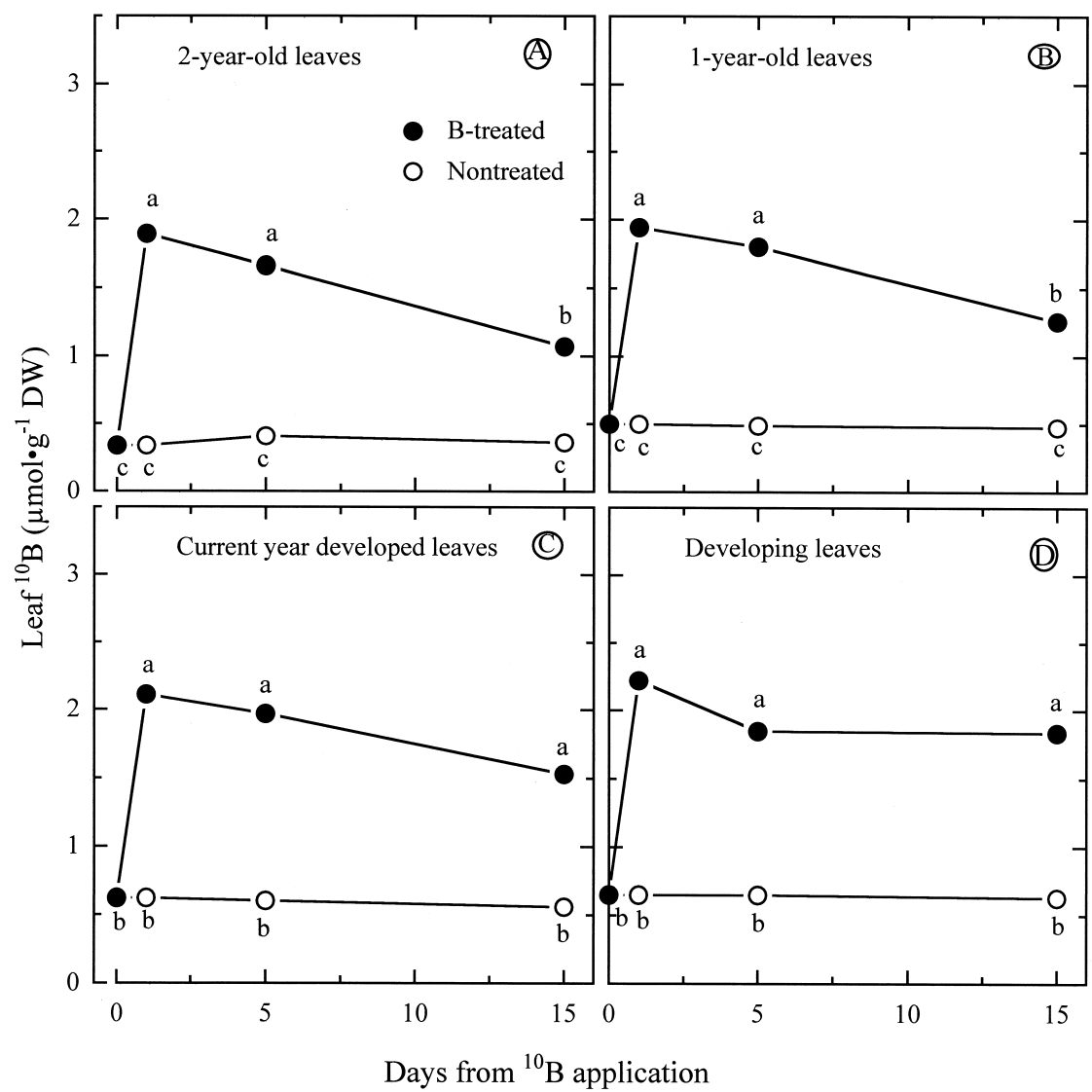




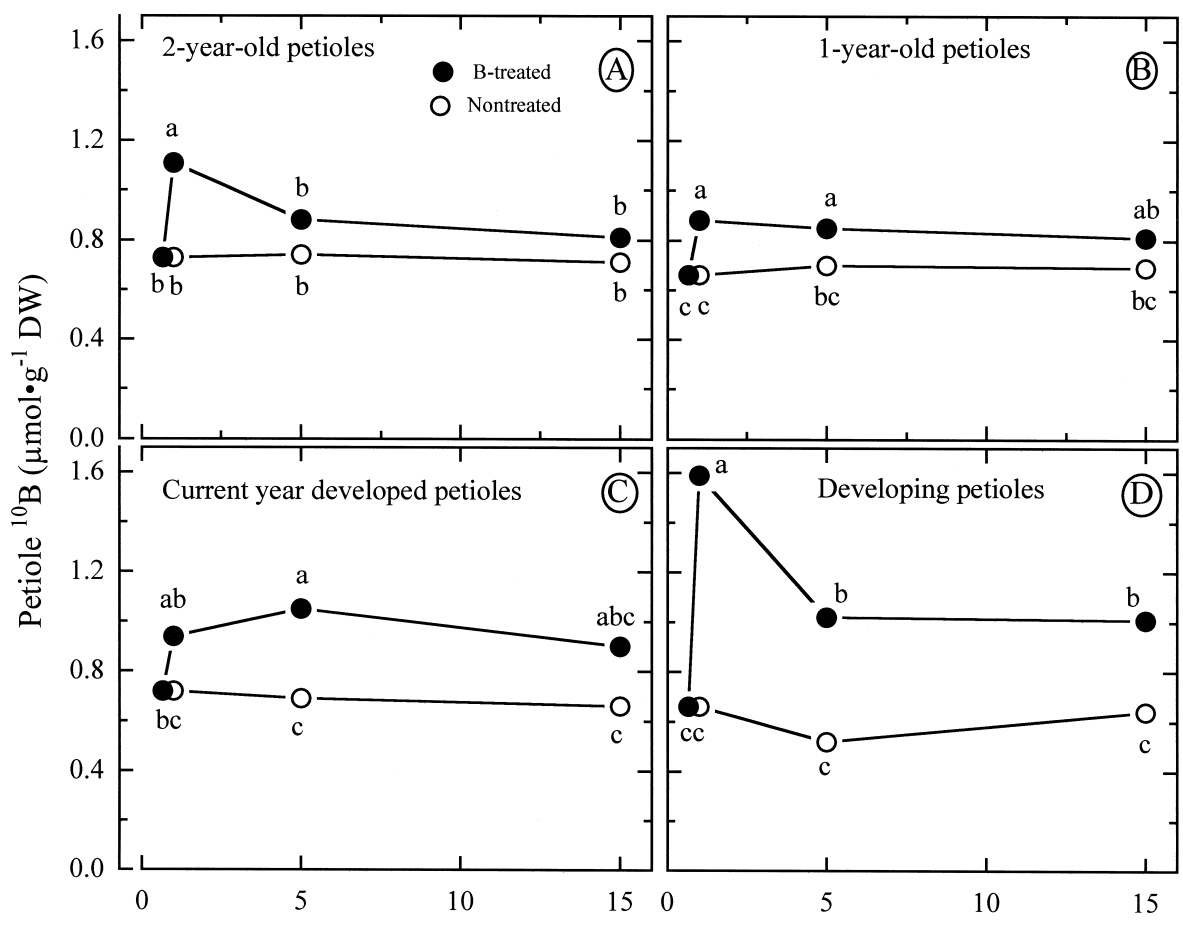

Days from ${ }^{10} \mathrm{~B}$ application

\section{Discussion}

Results indicate that translocation of B from olive leaves occurs during inflorescence development and rapid fruit growth. This was demonstrated by disappearance of labeled B from the treated leaves and the appearance of labeled B in the nontreated organs, such as inflorescences, petioles, peduncles, and fruit. Further evidence of phloem $B$ translocation from mature olive leaves was provided by observation of higher B concentration in young than old leaves, which is typical of species in which B is phloemmobile (Brown and $\mathrm{Hu}, 1998$; Brown and Shelp, 1997; Brown et al., 1999b). However, the translocation of B from the olive leaf was not apparently influenced by local sink strength, as removing inflorescences did not significantly affect translocation.

Boron plays an important though poorly understood role in reproduction, hence optimizing reproductive $\mathrm{B}$ status is critical to crop productivity. Many researchers have demonstrated that foliar application of B, immediately prior to flowering, effectively increases inflorescence $\mathrm{B}$ concentration and subsequent fruit set in field-grown tree spe-

Fig. 4. Changes in petiole ${ }^{10} \mathrm{~B}$ concentration after $100 \mathrm{~mm}{ }^{10} \mathrm{~B}$-enriched boric acid foliar application to petiole-associated leaf blades on 4 Aug.; (A) 2-year-old petioles, (B) 1-year-old petioles, (C) current year developed petioles, and (D) developing petioles. Boron concentration on day 0 preceded foliar application. Data points with different letters differ at $P<0.05$ by Fisher's protected LSD. Mean separation $(n=5)$ is across B treatments and across dates.

cantly increased mannitol concentration in the current-yeardeveloped leaves compared with controls.

No effect of $\mathrm{B}$ on mannitol concentration in fruit, fruit peduncles or shoot tips was observed. The lowest concentration of mannitol was found in the fruit $\left(14.5 \mu \mathrm{mol} \cdot \mathrm{g}^{-1} \mathrm{FW}\right)$, followed by the fruit peduncles $\left(28 \mu \mathrm{mol} \cdot \mathrm{g}^{-1} \mathrm{FW}\right)$ and the highest mannitol concentration was found in shoot tips $\left(65 \mu \mathrm{mol} \cdot \mathrm{g}^{-1} \mathrm{FW}\right)$.

The concentration of glucose (Fig. 7) in the leaves was generally 2 -fold higher than that of mannitol in the same tissues. In B-treated leaves, 2-year-old leaves had significantly lower glucose concentration than that of younger leaves. Boron did not affect glucose levels in the leaves $24 \mathrm{~h}$ after application (Fig. 7).

The concentration of glucose in the petioles of control leaves (Fig. 8) was generally 50\% lower than the concentration in the leaf blades. The petioles of the youngest developing leaves had the highest glucose concentration. Application of B to leaves significantly and uniformly reduced the concentration of glucose in the petioles by $>50 \%$. This decrease in glucose was generally not offset by the increase in mannitol except for the current-year-developed leaves (Fig. 6). Boron application did not increase nor decrease any other sugars in significant quantity in the petioles (sugars other than mannitol or glucose accounted for only $\approx 10 \%$ to $18 \%$ of the total sugar concentration on a FW basis).

No statistically significant effect of B application on glucose concentration in the fruit and fruit peduncles could be observed. Glucose in the control fruit peduncles was $13 \mu \mathrm{mol} \cdot \mathrm{g}^{-1} \mathrm{FW}$ and that of B treated ones was $15.5 \mu \mathrm{mol} \cdot \mathrm{g}^{-1} \mathrm{FW}$. Glucose in the nontreated fruit was $75 \mu \mathrm{mol} \cdot \mathrm{g}^{-1} \mathrm{FW}$ and in B treated was $85 \mu \mathrm{mol} \cdot \mathrm{g}^{-1} \mathrm{FW}$, respectively. cies including, almond (Prunus dulcis Mill D.A. Webb) (Nyomora et al., 1997, 1999), sour cherry (Prunus cerasus L.) (Hanson, 1991), and olive (S. Perica and P.H. Brown, unpublished data). The mechanism by which foliar-applied B stimulates reproductive effectiveness is unknown, however, there is evidence to suggest a role of B in hormonal regulation (Blevins and Lukaszewski, 1998) or translocation of sugars (Gauch and Dugger, 1953). The importance of $\mathrm{B}$ in reproductive growth and the significance of plant response to supplemental B illustrate the importance of understanding the dynamics of $B$ transport in plants.

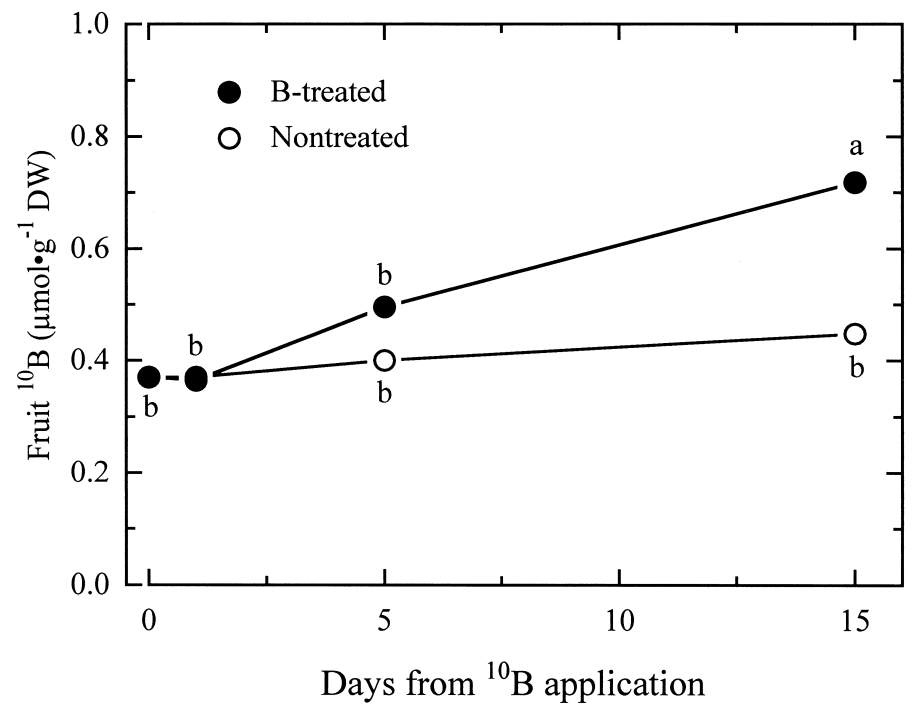

Fig. 5. Changes in fruit ${ }^{10} \mathrm{~B}$ concentration after $100 \mathrm{~mm}{ }^{10} \mathrm{~B}$-enriched boric acid foliar application on 4 Aug. to adjacent 2-year-old, 1-year-old, current-yeardeveloped, and developing leaves. Boron concentration on day 0 preceded foliar application. Data points with different letters differ at $P<0.05$ by Fisher's protected LSD. Mean separation $(n=5)$ is across B treatments and across dates. 


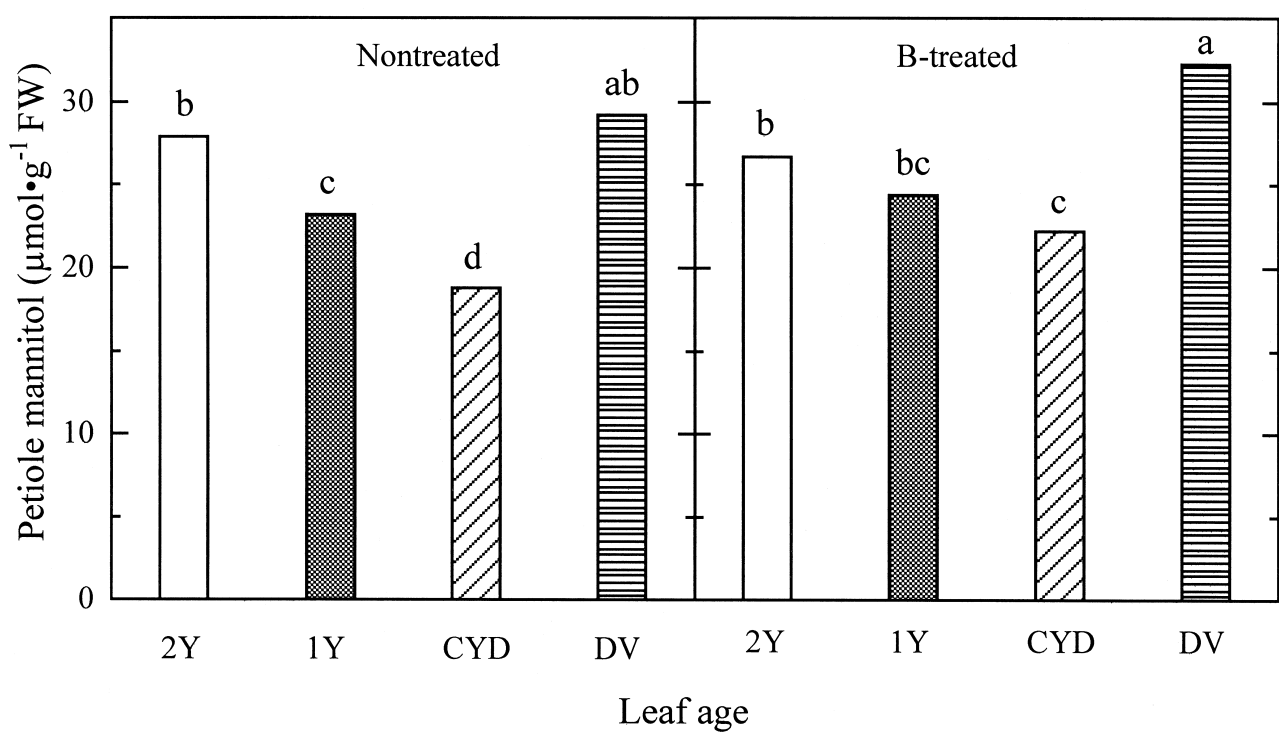

Dugger, 1953; Goldbach, 1997). Indeed a role for B in sugar translocation was the first proposed role of $\mathrm{B}$ in the plant (Gauch and Dugger, 1953). In these early experiments B application was shown to increase the export of sucrose from treated leaves. More recently, Bellaloui et al. (1999) demonstrated that the concentration of leaf sorbitol increased with B application in transgenic tobacco (Nicotiana tabacum L.) in which the gene for sorbitol production had been incorporated (Tao et al., 1995). In the present study, foliar $B$ application significantly decreased glucose concentrations in the petioles of all leaf ages, while a concomitant increase of mannitol was only observed in the petioles of current-

Fig. 6. Petiole mannitol concentration $1 \mathrm{~d}$ after $100 \mathrm{~mm}{ }^{10} \mathrm{~B}$-enriched boric acid foliar application on 4 Aug. ( $2 \mathrm{Y}=2$-year leaves, $1 \mathrm{Y}=1$-year leaves, $\mathrm{CYD}=$ current-year-developed leaves, and DV $=$ developing leaves, respectively). Bars with different letters differ at $P<0.05$ by Fisher's protected LSD. Mean separation $(n=5)$ is across B treatments and across leaves of different ages.

Results presented herein demonstrate that leaves of all age groups have the capacity to translocate B in olive. The apparent mobility of B at two important stages of olive growth, and translocation of $\mathrm{B}$ to developing tissues demonstrates that foliar $\mathrm{B}$ application can be used effectively at any of the stages of olive development tested herein.

Phloem B mobility has been found to be associated with the movement of sugar alcohols (Brown et al., 1999a; Brown and Hu, 1996; Hu et al., 1997). Soluble sugar analysis revealed that leaves of all age groups have similar mannitol concentrations and suggested that mannitol produced in the leaves is exported out of the leaves as it is found in high concentrations in the petioles. The presence of mannitol and the enrichment of ${ }^{10} \mathrm{~B}$ in the petioles suggest the physiological significance of B-mannitol complexation as reported previously (Brown and $\mathrm{Hu}, 1996$; $\mathrm{Hu}$ et al., 1997). On a FW basis, total B concentration in the petioles was $\approx 1$ $\mathrm{mm}$, while mannitol in petiole ranged $\approx 20$ to $30 \mathrm{~mm}$. With this high mannitol and low $\mathrm{B}$ ratio, essentially all the free B would be complexed and transported as mannitol-B-mannitol complex (Hu et al., 1997; Makkee et al., 1985).

Whereas the biochemical basis for mannitol facilitated B remobilization is now well established (Brown et al., 1999a; Brown and Shelp, 1997; Hu et al., 1997), the possible roles of supplemental B on translocation of soluble carbohydrates are poorly understood. Evidence for an interaction between supplemental B and sugar translocation has been observed, or hypothesized, by several authors (Bellaloui et al., 1999; Gauch and

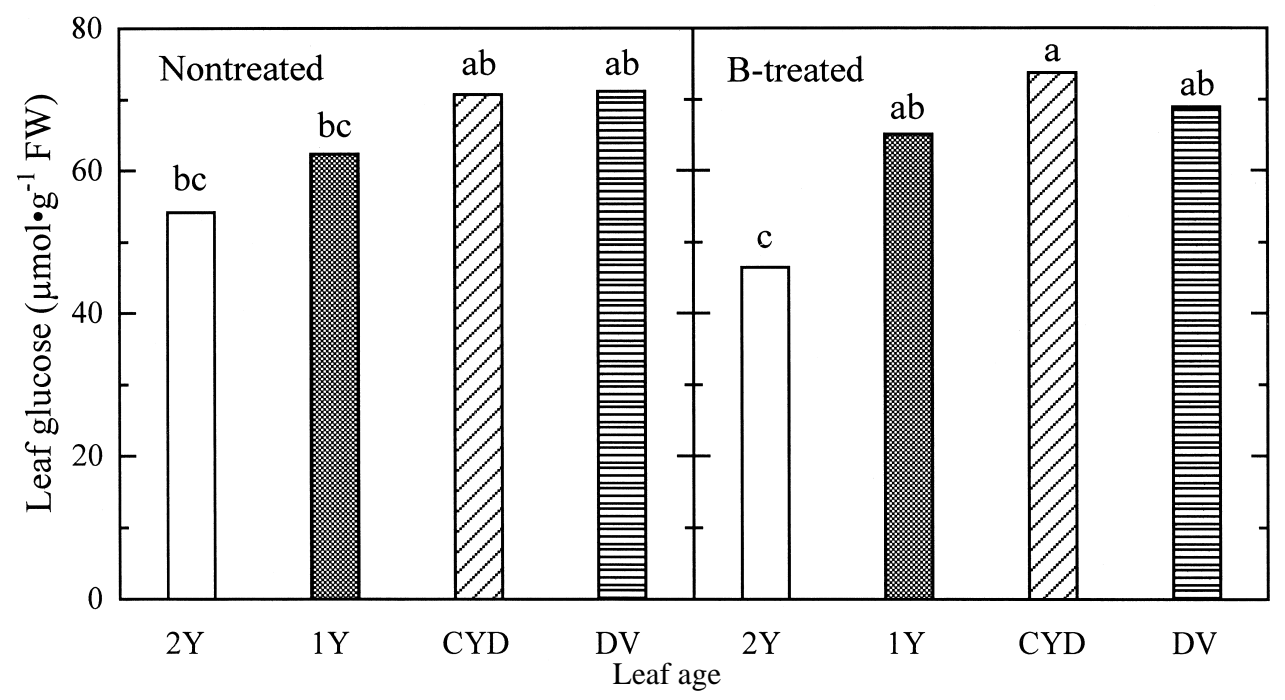




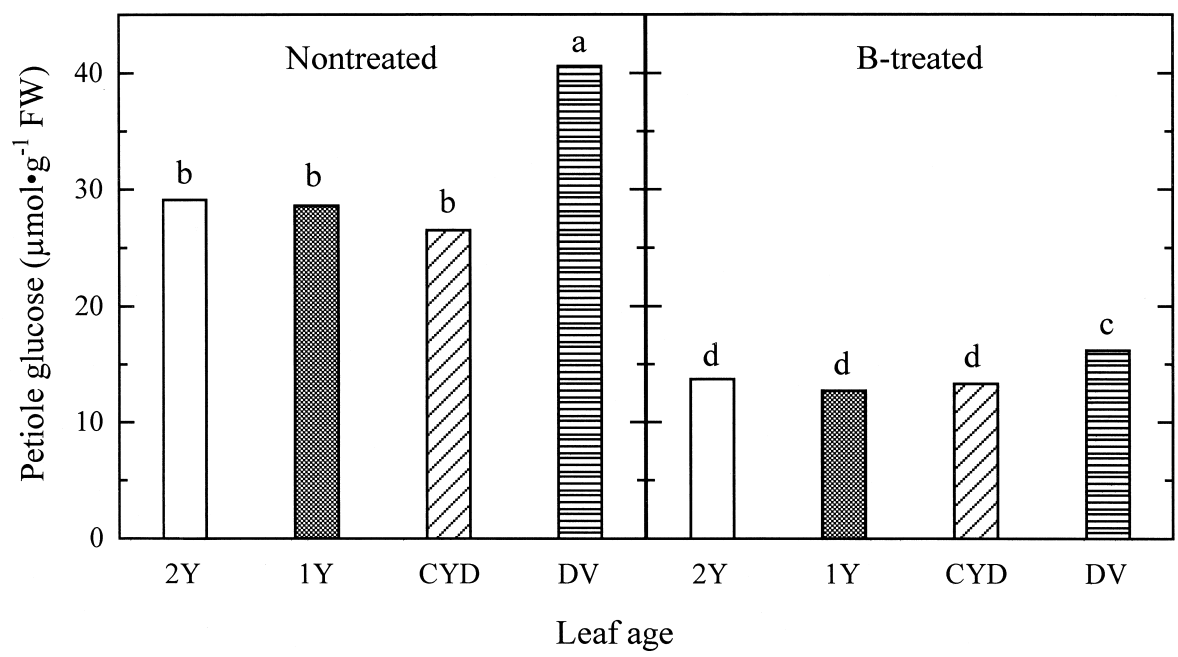

Fig. 8. Petiole glucose concentration $1 \mathrm{~d}$ after $100 \mathrm{~mm}{ }^{10} \mathrm{~B}$-enriched boric acid foliar application on $4 \mathrm{Aug}(2 \mathrm{Y}=2$-year leaves, $1 \mathrm{Y}=1$-year leaves, $\mathrm{CYD}=$ current-year-developed leaves, and DV = developing leaves, respectively). Bars with different letters differ at $P<0.05$ by Fisher's protected LSD. Mean separation $(n=5)$ is across B treatments and across leaves of different ages.

metabolic effect. Interestingly, boronic acids have been discovered to facilitate sugar transport through artificial lipid bilayer membranes (Westmark et al., 1996), via a physicochemical process entirely consistent with the Goldbach (1997) hypothesis.

There is substantial and increasing evidence that B plays a unique role in reproduction and supplemental B application improves pollen viability (Lovatt and Dugger, 1984; Robbertse et al., 1990), flower development (Dell and Huang, 1997; Rawson, 1996), seed set (Mozafar, 1993), fruit retention (Blevins et al., 1996; Brown et al., 1999a), and final fruit size (Smith et al., 1997) even in the absence of any signs of vegetative B deficiency. A role for B in sugar transport and utilization by developing pollen and embryos, fruit, and seeds would be consistent with these widely observed effects of $\mathrm{B}$ on reproduction and the present results. While a role for B in cell wall structure and function is well accepted, other role(s) for B remain unknown. The historical evidence for a role of $\mathrm{B}$ in membranes and sugar transport and evidence for an effect of B on soluble carbohydrate concentrations described herein and elsewhere (Bellaloui et al., 1999) are intriguing and deserving of further study.

\section{Literature Cited}

Bellaloui, N., P.H. Brown, and A.M. Dandekar. 1999. Manipulation of in vivo sorbitol production alters boron uptake and transport in tobacco. Plant Physiol. 119:735-741.

Blevins, D.G. and K.M. Lukaszewski. 1998. Boron in plant structure and function. Annu. Rev. Plant Physiol. Plant Mol. Biol. 49:481-500.

Blevins, D.G., C.L. Scrivner, and T.M. Reinbott. 1996. Foliar boron increases berry number and yield of two highbush blueberry cultivars in Missouri. J. Plant Nutr. 19:99-113.

Brown,P.H,N.Bellaloui,H.Hu, and A. Dandekar. 1999a. Transgenically enhanced sorbitol synthesis facilitates phloem boron transport and increases tolerance of tobacco to boron deficiency. Plant Physiol. 119:17-20.

Brown, P.H. and H. Hu. 1994. Boron uptake by sunflower, squash and cultured tobacco cells. Physiol. Plant. 91:435-441.

Brown, P.H. and H. Hu. 1996. Phloem mobility of boron is species dependent: Evidence for phloem mobility in sorbitol-rich species. Ann. Bot. 77:497-505.

Brown, P.H. and H. Hu. 1998. Phloem boron mobility in diverse plant species. Bot. Acta. 111:331-335.

Brown, P.H., H. Hu, and W.G. Roberts. 1999b. Occurrence of sugar alcohols determines boron toxicity symptoms of ornamental species. J. Amer. Soc. Hort. Sci. 124:347-352.

Brown, P.H. and B.J. Shelp. 1997. Boron mobility in plants. Plant Soil 193:85-101.

Delgado A., M.Benlloch, and R. Fernandez-Escobar. 1994. Mobilization of boron in olive trees during flowering and fruit development. HortScience 29:616-618.

Dell, B. and L. Huang. 1997. Physiological response of plants to low boron. Plant Soil 193:103-120.

Drossopoulos, J.B. and C.A. Niavis. 1988. Seasonal changes of the metabolites in the leaves, bark and xylem tissues of olive tree (Olea europaea. L). II. Carbohydrates. Ann. Bot. 62:321-327.

Flora, L.L. and M.A. Madore. 1993. Stachyose and mannitol transport in olive (Olea europaea L.). Planta 189:484-490

Garcia P., M. Brenes, C. Romero, and A. Garrido. 1995. Respiration and physicochemical changes in harvested olive fruits. J. Hort. Sci. 70:925-933.

Gauch, H.G. and W.M. Dugger, Jr. 1953. The role of boron in the translocation of sucrose. Plant Physiol. 28:457-466.

Goldbach, H.E. 1997. A critical review on current hypotheses concerning the role of boron in higher plants: Suggestions for further research and methodological requirements. J. Trace and Microprobe Technol. 15:51-91.

Greve, L.C. and J.M. Labavitch. 1991. Cell wall metabolism in ripening fruit .5. Analysis of cell wall synthesis in ripening tomato pericarp tissue using a D-[U13c]glucose tracer and gas-chromatography mass-spectrometry. Plant Physiol. 97:1456-1461.

Hanson, E.J. 1991. Sour cherry trees respond to foliar boron applications. HortScience 26:1142-1145.

Hu H., S.G. Penn, C.B. Lebrilla, and P.H. Brown. 1997. Isolation and characterization of soluble boron complexes in higher plants. The mechanism of phloem mobility of boron. Plant Physiol. 113:649-655.

Lovatt, C.J. and W.M. Dugger. 1984. Boron, p. 389-420. In: E. Frieden (ed.). Biochemistry of the essential ultratrace elements. Plenum Publishing Corp. New York.

Makkee, M., A.P.G. Kieboom, and H. van Bekkum. 1985. Studies on borate esters. III. Borate esters of D-mannitol, D-glucitol, D-fructose and D-glucose in water. Recl. Trav. Chim. Pays-Bas. 104:230-235.

Mozafar, A. 1993. Role of boron in seed production, p. 186-206. In: U.C. Gupta (ed.). Boron and its role in crop production. CRC Press, Boca Raton, Fla.

Nyomora, A.M.S., P.H. Brown, and M. Freeman. 1997. Fall foliar-applied boron increases tissue boron concentration and nut set of almond. J. Amer. Soc. Hort. Sci. 122:405-410.

Nyomora, A.M.S., P.H. Brown, and B. Krueger. 1999. Rate and time of boron application increase almond productivity and tissue boron concentration. HortScience 34:242-245.

Robbertse, P.J., J.J. Lock, E. Stoffberg, and L.A. Coetzer. 1990. Effect of boron on directionality of pollen tube growth in Petunia and Agapanthus. S. Afr. J. Bot. 56:487-492.

Rawson,H.M. 1996. The developmental stage during which boron limitation causes sterility in wheat genotypes and the recovery of fertility. Austral. J. Plant. Physiol. 23:709-717.

Smith, T.E., C.J. Asher, R.A. Stephenson, and S.E. Hetherington. 1997. Boron deficiency of avocado. 2. Effects on fruit size and ripening, p. 135-137. In: R.W Bell and B. Rerkasem (eds.). Boron in soils and plants. Kluwer Academic Publishers, The Netherlands.

Tao, R., S.L. Uratsu, and A.M. Dandekar. 1995. Sorbitol synthesis in transgenic tobacco with apple cDNA encoding NADP-dependent sorbitol-6-phosphate dehydrogenase. Plant Cell Physiol. 36:525-532.

Tattini M., R. Gucci, A. Romani, A. Baldi, and J.D. Everard. 1996. Changes in nonstructural carbohydrates in olive (Olea europaea L.) leaves during root zone salinity stress. Physiol. Plant. 98:117-124.

Westmark, P.R., S.J. Gardiner, and B.D. Smith. 1996. Selective monosaccharide transport through lipid bilayers using boronic acid carriers. J. Amer. Chem. Soc. 118:11093-11100. 